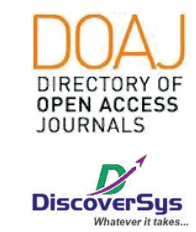

Published by DiscoverSys

\section{Hubungan proteinuria dan batu saluran kemih: Studi analitik}

\author{
Zulfikar Ali, ${ }^{1 *}$ Eko Arianto
}

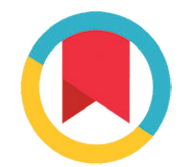

CrossMark

\title{
ABSTRACT
}

Background: Urinary tract stones (UTS) are still one of the most common problems faced by urologists. Proteinuria can be found in the condition of chronic kidney failure (CRF), urinary tract infections (UTI), malignancy, or UTS. Urine protein is known to play a role in the process of BSK supersaturation and aggregation. $A$ recent study found an association of urine marker protein with UTS at the molecular level after the electrophoresis process. This study aims to determine the relationship of proteinuria in urinalysis with UTS.

Methods: This study was a cross-sectional study of polyurological patients in Kardinah Regional General Hospital, Tegal. A total sample of 200 patients were grouped into 100 BSK patients and 100 control patients. All patients underwent ultrasound examination (USG) as an initial diagnosis, then a urinalysis examination. Proteinuria is considered positive for urine protein values +1 to +4 and negative for trace and negative urine protein values. Other variables analyzed were UTI, urine $\mathrm{pH}$, age, and gender.

Results: Male patients have a higher tendency to UTS compared to women with a ratio of 1.8: 1 . The age range of the UTS group is 23-78 years and in the control group 17-85 years. No significant relationship was found between proteinuria and UTS( $p=0.203)$. There is a relationship between UTI and UTS $(p=0.002)$ and urine $\mathrm{pH}$ with UTS $(p=0.024)$. There was a relationship between UTI and proteinuria in univariate and multivariate tests $(p=0.000)$.

Conclusion: There is no relationship between proteinuria with UTS. There is a relationship between proteinuria and UTI. Proteinuria arises because of the inflammatory process in cases of infection due to stones. Further research is needed to determine the type of urine protein that is an inhibitor in non stone former patients and the type of urine protein found in stone former.

Keywords: urinalysis, proteinuria, albuminuria, infection, urinary tract stones, stone former

Cite This Article: Ali, Z., Arianto, E. 2020. Hubungan proteinuria dan batu saluran kemih: Studi analitik. Intisari Sains Medis 11(1): 286-290. D0I: 10.15562/ism.v11i1.613

\section{ABSTRAK}

Latar Belakang: Batu saluran kemih (BSK) masih merupakan salah satu masalah tersering yang dihadapi urolog. Proteinuria dapat ditemukan pada kondisi gagal ginjal kronis (GGK), infeksi saluran kemih (ISK), keganasan, ataupun BSK. Protein urin diketahui berperan dalam proses supersaturasi dan agregasi BSK. Studi terkini menemukan hubungan protein marker urin dengan BSK pada level molekular setelah proses elektroforesis. Penelitian ini bertujuan untuk mengetahui hubungan proteinuria pada urinalisa dengan BSK.

Spesialis Urologi, Departemen Bedah, Divisi Urologi, Rumah Sakit Kardinah, Tegal, Indonesia ${ }^{2}$ Residen Urologi, Fakultas Kedokteran, Universitas Indonesia, Jakarta

*Korespondensi: dr. Zulfikar Ali; Departemen Bedah, Divisi Urologi, RSUD Tegal;

zulfikar_74@yahoo.com

Diterima: 07-01-2020

Disetujui: 20-03-2020

Diterbitkan: 27-03-2020 negatif. Variabel lain yang dianalisa adalah ISK, ph urin, usia, dan jenis kelamin.

Hasil: Pasien laki-laki memiliki kecenderungan BSK yang lebih tinggi dibandingkan perempuan dengan rasio 1,8:1. Rentang usia kelompok BSK 23-78 tahun dan pada kelompok kontrol 17-85 tahun. Tidak didapatkan hubungan yang bermakna antara proteinuria dengan BSK $(p=0,203)$. Terdapat hubungan antara ISK dengan BSK $(p=0,002)$ dan ph urin dengan BSK $(p=0,024)$. Terdapat hubungan antara ISK dengan proteinuria pada uji univariat dan multivariat $(p=0,000)$.

Simpulan: Tidak didapatkan hubungan antara proteinuria dengan BSK. Terdapat hubungan antara proteinuria dengan ISK. Proteinuria muncul karena proses inflamasi pada kasus infeksi akibat batu. Penelitian lanjutan diperlukan untuk menentukan jenis protein urin yang menjadi inhibitor pada pasien non stone former dan jenis protein urin yang ditemukan pada stone former. 


\section{PENDAHULUAN}

Teori pembentukan batu saluran kemih (BSK) bermula dari proses saturasi. Pada kondisi urin supersaturasi, faktor promotor dan inhibitor menjadi tidak seimbang, sehingga terbentuklah nukleasi dan matrix batu. Klasifikasi batu menurut European Association of Urology (EAU), dapat dibagi menjadi batu infeksi, batu non-infeksi, batu genetik, dan batu medikamentosa. Diagnostik baku emas untuk batu saluran kemih adalah CT urografi tanpa kontras. Sementara untuk analisa laboratorium, urinalisa merupakan rekomendasi grade A. ${ }^{1,2}$

Proteinuria pertama kali dideskripsikan lebih dari 200 tahun yang lalu ketika Hippocrates membuat hipotesa hubungan antara urin berbuih dengan penyakit ginjal. Saat ini proteinuria didefinisikan sebagai ekskresi protein urin lebih dari $150 \mathrm{mg} / \mathrm{hari}$. Berdasarkan penyebabnya, proteinuria dapat diklasifikasikan menjadi glomerular (akibat glomerulopati), tubular (penyakit tubulus), atau overflow (peningkatan produksi protein). Secara klinis penyebab proteinuria dapat juga diklasifikasikan menjadi prerenal, renal, dan postrenal. Penyebab prerenal adalah bence jones protein, suatu gamma globulin abnormal yang ditemukan pada multiple myeloma. Sementara penyebab renal dapat berupa glomerulonefritis, sindrom nefrotik, akibat lisis muskular, maupun penyakit ginjal akut dan kronik. Fokus penelitian ini adalah pada penyebab postrenal proteinuria, yaitu akibat proses inflamasi traktus urinarius yang dapat berasal dari tumor, infeksi, atau batu saluran kemih., ${ }^{2,3}$

Studi oleh Haley dkk pada tahun 2016 di Mayo Clinic mencoba membuktikan penurunan fungsi ginjal setelah kejadian BSK pertama dengan membandingkan kelompok stone former dengan non stone former. Hasilnya pada kelompok stone former, didapatkan kadar protein yang lebih tinggi, dan kecenderungan untuk mengalami albuminuria, pada nilai kreatinin serum yang tidak berbeda. Hasil ini tidak berubah setelah dilakukan followup 3 bulan oleh peneliti. ${ }^{4}$

Bergsland dkk dari University of Chicago menemukan bahwa marker protein urin dapat membedakan individu dengan risiko stone former dan non stone former. Mereka melakukan analisa elektroforesis protein urin dan berkesimpulan bahwa inter-a-trypsin inhibitor (ITI), prothrombin fragment 1 (PF1), CD59, dan calgranulin B (calB) berhubungan dengan angka kejadian dan rekurensi batu saluran kemih. ${ }^{5}$

Penggunaan analisa elektroforesis urin masih sangat jarang dilakukan dan membutuhkan biaya yang besar di Indonesia. Oleh karena itu, peneliti bertujuan untuk mencari hubungan antara temuan proteinuria pada urinalisa dengan batu saluran kemih.

\section{METODE}

Design penelitian ini merupakan studi analitik potong lintang. Subjek penelitian adalah seluruh pasien dewasa di poli urologi rumah sakit Kardinah periode Januari - Maret 2019. Metode pengambilan sampel dengan matched concecutive sampling. Seluruh subjek dilakukan pemeriksaan ultrasound (USG) sebagai langkah diagnostik awal. Pada pasien dengan temuan hidronefrosis atau batu dari USG, dilakukan pemeriksaan radiologis lanjutan sesuai dengan keperluan diagnostik. Kemudian seluruh pasien kelompok BSK dan kontrol dilakukan pemeriksaan urinalisa.

Terdapat total 200 subjek pada penelitian ini. Kami membagi kelompok menjadi 100 pasien dengan batu saluran kemih dan 100 pasien kelompok kontrol tanpa batu saluran kemih. Pasien dengan hasil protein pada urinalisa $1+$ atau lebih dikelompokan sebagai proteinuria. Sementara pasien dengan hasil protein negatif dan trace dikelompokan sebagai negatif. Dilakukan matching umur dan gender untuk kedua kelompok.

Pengolahan data menggunakan program SPSS versi 20. Data kategorik ditampilkan dalam tabel frekuensi dan analisa dengan uji chi square. Sementara untuk data numerik dilakukan uji normalitas terlebih dahulu dengan uji Kolmogorv Smirnov dan analisa dengan uji T. Uji multivariat dilakukan dengan regresi logistik. Hasil dinilai bermakna secara statistik bila nilai $\mathrm{p}<0,05$.

\section{HASIL}

Kami mengumpulkan 200 rekam medis yang dikelompokan menjadi kelompok kasus dan kelompok kontrol. Tabel 1 menampilkan karakteristik dasar pasien, seperti usia dan jenis kelamin dicatat pada kunjungan pertama pasien. Data lain seperti hasil urinalisa dan lokasi batu juga ditampilkan pada tabel 1.

Hasil analisa hubungan antara proteinuria dan variabel lain dengan batu saluran kemih ditampilkan pada tabel 2. Uji statistik dilakukan untuk variabel nominal dan numerik dan ditampilkan juga pada tabel 2.

Hasil analisa hubungan antara proteinuria dengan ISK dapat dilihat dari tabel 3. Hasil analisa multivariat untuk proteinuria dengan BSK dan faktor lain dibuat dengan regresi logistik dan ditampilkan pada tabel 4. 
Tabel 1 Karakteristik dasar dan hasil urinalisa pasien

\begin{tabular}{lcc}
\hline Variabel & BSK & Kontrol \\
\hline Karakteristik dasar & & $17-85(60)$ \\
Usia (median) & $23-78(49)$ & 78 \\
Jenis Kelamin & 65 & 22 \\
$\quad$ - Pria & 35 & - \\
$\quad$ - Wanita & & - \\
Lokasi Batu & 62 & - \\
$\quad$ - Ginjal & 33 & $5,8 \pm 1,08$ \\
$\quad$ - Ureter & 5 & $1,013 \pm 0,005$ \\
$\quad$ - Buli & & \\
Pemeriksaan Laboratorium & $5,5 \pm 0,69$ & 23 \\
pH urin (mean \pm SD) & $1,013 \pm 0,006$ & 77 \\
Berat jenis urin (mean \pm SD) & & 33 \\
Proteinuria & 31 & \\
$\quad$ - Ada & 69 & \\
- Tidak ada & & \\
Infeksi saluran kemih & 55 & \\
- Ada & 45 & \\
- Tidak ada & & \\
\hline
\end{tabular}

Tabel 2 Hubungan antara proteinuria dan variabel lain dengan BSK

\begin{tabular}{lccccc}
\hline Variabel & BSK & Kontrol & Total & Nilai p & IK 95\% \\
\hline Infeksi saluran kemih & & & & & \\
$\quad-\quad$ Ada & $55(27,5 \%)$ & $33(16,5 \%)$ & 88 & $0,002^{\mathrm{a}}$ & $1,4-4,4$ \\
$\quad$ - Tidak ada & $45(22,5 \%)$ & $67(33,5 \%)$ & 112 & & \\
Proteinuria & & & & $0,203^{\mathrm{a}}$ & $0,8-2,8$ \\
$\quad$ - Ada & $31(15,5 \%)$ & $23(11,5 \%)$ & 54 & & $0,04-0,54$ \\
$\quad$ - Tidak ada & $69(34,5 \%)$ & $77(38,5 \%)$ & 146 & $0,024^{\mathrm{b}}$ & 0 \\
pH urin & $5,5 \pm 0,69$ & $5,8 \pm 1,08$ & & & \\
\hline
\end{tabular}

a) uji chi square b) uji T tidak berpasangan

Tabel 3 Hubungan antara proteinuria dengan BSK

\begin{tabular}{lccccc}
\hline Variabel & ISK (+) & ISK (-) & Total & Nilai p & IK 95\% \\
\hline $\begin{array}{l}\text { Proteinuria } \\
\text { - Ada }\end{array}$ & 40 & & & & \\
$\quad-\quad$ Tidak ada & 48 & 98 & 54 & $0,000^{\text {a }}$ & $1,8-4,8$ \\
\hline
\end{tabular}

a) uji chi square

Tabel 4 Analisa multivariat proteinuria dengan BSK dan ISK

\begin{tabular}{lccccc}
\hline Proteinuria & $\mathbf{n}$ & $\mathbf{B}$ & Wald $\mathbf{X}^{2}$ & $\mathbf{p}$ & $\mathbf{C l} \mathbf{9 5 \%}$ \\
\hline BSK & 31 & 0,046 & 0,017 & 0,895 & $0,5-2,1$ \\
ISK & 40 & 1,753 & 23,072 & 0,000 & $2,8-11,8$ \\
\hline
\end{tabular}




\section{PEMBAHASAN}

Dari hasil penelitian kami, mayoritas pasien dengan batu berjenis kelamin laki-laki dengan perbandingan dengan perempuan 1,8:1. Pada kelompok kontrol, yaitu pasien poli urologi selain batu saluran kemih, juga didominasi laki-laki dengan perbandingan 3,5:1. Sementara rentang usia pasien dengan kelompok batu 23 sampai 78 tahun dengan median 49 tahun, untuk kelompok kontrol dari 17 sampai 85 tahun dengan median 60 tahun. Hal ini memberikan gambaran karakteristik dasar kedua kelompok tidak terlalu berbeda pada penilitian kami. Hal ini juga sesuai dengan data epidemiologi yang menunjukkan laki-laki memiliki risiko 2-3 kali lebih tinggi untuk menderita BSK. ${ }^{1}$ Meskipun trend saat ini menunjukkan rasio tersebut semakin menurun dan mengurangi perbedaan gender terhadap kejadian batu saluran kemih. Di America tren menurun dari 1,7 pada tahun 1997 menjadi 1,3 pada 2002. ${ }^{6}$ Database lain dari Rochester menunjukkan tren menurun dari 3,2 pada tahun 1970 menjadi 1,3 pada tahun $2000 .^{7}$ Database Marshfield mencatat penurunan dari 1,4 pada tahun 1992 menjadi 1,0 pada tahun 2008. ${ }^{8}$ Perbedaan rasio gender juga masih lebih tinggi laki-laki pada negara Asia seperti di Iran (1:15), Thailand (1:6), Irak (2:5), maupun Arab Saudi $(5: 0) .^{9-12}$

Temuan klinis proteinuria mengandung berbagai protein dari berat molekul dan asal yang berbeda. Sekitar 20\% dari protein normal yang diekskresikan merupakan low molecular weight protein, 40\% merupakan high molecular weight protein, dan $40 \%$ lainnya adalah Tamm-Horsfall mucoprotein yang dieksresikan dari tubulus distal. Proteinuria dapat diukur secara sederhana dengan menggunakan urin dipstik yang diinterpretasikan sebagai: negatif ( $<10 \mathrm{mg}$ per $\mathrm{dL})$, trace $(10-20 \mathrm{mg}$ per $\mathrm{dL}), 1+(30 \mathrm{mg}$ per $\mathrm{dL}), 2+(100 \mathrm{mg}$ per $\mathrm{dL}), 3+$ (300 $\mathrm{mg}$ per $\mathrm{dL}$ ) atau $4+(1,000 \mathrm{mg}$ per $\mathrm{dL}){ }^{3,5}$

Penelitian kami menunjukkan tidak ada hubungan yang bermakna secara statistik antara proteinuria dan BSK ( $p=0,203)$. Secara teoritis, protein yang dapat terdeteksi pada urin dipstik, adalah protein makromolekul yang pada kondisi glomerulus normal, tidak dapat melewati barrier. Pada kasus BSK maupun ISK, inflamasi yang ditimbulkan pada jaringan sekitar dapat memicu kerusakan tingkat seluler sehingga merusak sistem barrier. Protein tersebut kemudian menjadi matriks yang berperan dalam proses saturasi terbentuknya batu. ${ }^{3}$

Kondisi gagal ginjal kronik (GGK) diketahui dapat menimbulkan BSK. Menurut Rule dkk, kondisi sebaliknya juga dapat berlaku karena pasien dengan BSK dapat menjadi GGK. Temuan proteinuria pada pasien dengan GGK mengarah pada stone former, dan temuan proteinuria pada pasien dengan riwayat BSK dapat menjadi GGK. ${ }^{13}$

Hubungan proteinuria dengan BSK ditemukan pada penyakit herediter. Pasien dengan kelainan Dent's memiliki tampilan klinis BSK rekuren, nefrokalsinosis, dengan hiperkalsiuria dan proteinuria. Penyakit ini diturunkan melalui kromosom X resesif berefek pada mutasi pompa $\mathrm{Na}$ dan K pada tubulus proksimal ginjal. Protein yang ditemukan dalam urin pasien dengan kelainan Dent merupakan low molecular weight protein. ${ }^{14}$ Hellemans dkk di Belgia pada tahun 2010 juga melaporkan kasus pasien stone former dengan BSK rekuren dan temuan klinis proteinuria yang konsisten. Pasien ini tidak memiliki riwayat keluarga BSK, namun hasil pemeriksaan genetik menegakkan diagnosis Dent. $^{15}$

Faktor lain yang dapat menimbulkan proteinuria adalah pola diet, usia, indeks massa tubuh, dan faktor metabolik lain. Suatu penelitian oleh Lin dkk di Harvard pada tahun 2011 meneliti total 3121 sampel, dan menemukan bahwa pasien dengan mikroalbuminuria memiliki usia yang lebih tua, hipertensi, diabetes, penyakit kardiovaskular, indeks massa tubuh yang lebih tinggi, dan pola diet yang tinggi protein. Pada analisa multivariat, didapatkan pola diet tinggi protein memiliki hubungan langsung dengan temuan mikroalbuminuria dibandingkan dengan diet tinggi serat. Penelitian ini juga menyimpulkan, pasien dengan pola diet tinggi protein memiliki rasio dua kali lebih tinggi untuk mengalami mikroalbuminuria dan risiko menderita GGK yang lebih tinggi. ${ }^{16}$

Studi lain membahas peranan protein urin dalam proses pembentukan batu pada tingkat molekuler. Suatu studi oleh Kumar dkk mengatakan bahwa makromolekul urin dengan berat molekul $>10 \mathrm{kD}$ meliputi kristal kalsium oksalat dan mencegah perlengketan dengan sel ginjal. Hal ini menjelaskan peran inhibitor protein urin dalam pembentukan BSK. Pada pasien dengan laki-laki dengan stone former, kemampuan inhibisi protein ini menurun sehingga terbentuk BSK. ${ }^{17}$ Bergsland dkk mengatakan marker protein urin dapat membedakan antara stone former dengan non stone former. Dengan melakukan elektroforesis dan Western Blot, berbagai bentuk dan jenis protein dapat dipisahkan, kemudian dilakukan analisa secara univariat dan multivariat. Beberapa protein seperti inter-a-trypsin inhibitor (ITI), prothrombin fragment 1 (PF1), CD59, dan calgranulin B (calB) ditemukan lebih tinggi pada kelompok stone former. ${ }^{5}$ Studi oleh 
Haley dkk juga membuktikan peran proteinuria pada kasus BSK rekuren dengan membandingkan kelompok stone former dengan non stone former dan dilakukan followup 3 bulan. Pada kelompok stone former, didapatkan kadar protein urin yang lebih tinggi. ${ }^{4}$

Hasil temuan studi kami dapat dijelaskan oleh penelitian lain sebelumnya. Hasil proteinuria yang tidak signifikan berhubungan dengan BSK menjadi rancu karena pemeriksaan protein urin pada urinalisa merupakan pemeriksaan awal yang tidak memisahkan jenis-jenis protein urin. Ini menjadi keterbatasan penelitian kami dan untuk selanjutnya dapat dikembangkan untuk mencari jenis protein urin yang memiliki efek inhibitor pada non stone former dan jenis protein yang ditemukan pada stone former.

Faktor lain yang kami temukan pada penelitian ini adalah infeksi dan ph urin. Kami menemukan hubungan yang bermakna antara ISK dan BSK (nilai $\mathrm{p}=0,02$ ). Hubungan yang bermakna juga didapatkan pada ph urin dengan BSK, yaitu pada kelompok BSK memiliki rerata ph yang lebih asam (nilai $\mathrm{p}=0,024$ ).

Kami menemukan bahwa proteinuria memiliki hubungan yang bermakna secara statistik dengan ISK $(p=0,000)$. Hubungan ini juga bermakna ketika dilakukan analisa multivariat dengan regresi logistik antara proteinuria dengan ISK dan BSK. Proteinuria pada data kami dapat dijelaskan oleh inflamasi yang muncul setelah proses infeksi akibat batu. Hal ini menunjukkan, proteinuria tidak berhubungan langsung dengan batu namun, memiliki hubungan pada kasus batu yang mengalami infeksi.

\section{SIMPULAN}

Tidak didapatkan hubungan antara proteinuria dengan BSK. Terdapat hubungan antara proteinuria dengan ISK. Proteinuria muncul karena proses inflamasi pada kasus infeksi akibat batu. Penelitian lanjutan diperlukan untuk menentukan jenis protein urin yang menjadi inhibitor pada pasien non stone former dan jenis protein urin yang ditemukan pada stone former.

\section{KONFLIK KEPENTINGAN}

Tidak ada konflik kepentingan dalam penelitian ini.

\section{PENDANAAN}

Tidak ada pendanaan khusus dalam pembuatan penelitian ini.

\section{KONTRIBUSI PENULIS}

Kedua penulis menyusun makalah, membaca dan menyetujui makalah akhir, dan bertanggung jawab dalam segala aspek dari makalah.

\section{REFERENCE/DAFTAR PUSTAKA (VANCOUVER STYLES)}

1. Wein AJ, Kavoussi LR, Partin AW, Peters CA. CampbellWalsh Urology. 11th ed. Elsevier; 2016.

2. Türk C, Vice-chair TK, Petrik A, Sarica K, Skolarikos A, Straub M, et al. EAU Guidelines on Urolithiasis. 2016;

3. Carroll MF, Temte JL, Ph D, Madison W. Proteinuria in Adults : A Diagnostic Approach. 2000;62(6):1-7.

4. Haley WE, Enders FT, Vaughan LE, Mehta RA, Thoman ME, Vrtiska TJ, et al. Kidney Function After the First Kidney Stone Event. 2016;91(12):1744-52.

5. Bergsland KJ, Kelly JK, Coe BJ, Coe FL, Kristin J, Kelly JK, et al. Urine protein markers distinguish stone-forming from non-stone-forming relatives of calcium stone formers. 2019;60612:530-6.

6. Scales CD, Curtis LH, Norris RD, Springhart WP, Sur RL, Schulman KA, et al. Changing Gender Prevalence of Stone Disease. J Urol. 2007;177(3):979-82.

7. Lieske JC, Peña De La Vega LS, Slezak JM, Bergstralh EJ, Leibson CL, Ho KL, et al. Renal stone epidemiology in Rochester, Minnesota: An update. Kidney Int. 2006;69(4):760-4.

8. Penniston KL, McLaren ID, Greenlee RT, Nakada SY. Urolithiasis in a rural Wisconsin population from 1992 to 2008: Narrowing of the male-to-female ratio. J Urol [Internet]. 2011;185(5):1731-6. Available from: http://dx. doi.org/10.1016/j.juro.2010.12.034

9. Khan A, Rai M, Gandapur, Pervaiz A, Shah A, Hussain A, et al. Epidemiological risk factors and composition of urinary stones in Riyadh Saudi Arabia. J Ayub Med Coll Abbottabad. 2004;15:56-8.

10. Safarinejad MR. Adult urolithiasis in a population-based study in Iran: Prevalence, incidence, and associated risk factors. Urol Res. 2007;35(2):73-82.

11. Tanthanuch M, Apiwatgaroon A, Pripatnanont C. Urinary tract calculi in southern Thailand. J Med Assoc Thai. 2005;88(1):80-5.

12. Qaader DS, Yousif SY, Mahdi LK. Prevalence and etiology of urinary stones in hospitalized patients in Baghdad. East Mediterr Heal J. 2006;12(6):853-61.

13. Rule AD, Krambeck AE, Lieske JC. Chronic kidney disease in kidney stone formers. Clin J Am Soc Nephrol. 2011;6(8):2069-75.

14. Vasudevan V, Samson P, Smith AD, Okeke Z. The genetic framework for development of nephrolithiasis. Asian J Urol [Internet]. 2017;4(1):18-26. Available from: http:// dx.doi.org/10.1016/j.ajur.2016.11.003

15. Hellemans R, Verpooten GA, Bosmans JL. A young man presenting with recurrent nephrolithiasis. NDT Plus. 2010;3(6):584-7.

16. Lin J, Fung TT, Hu FB, Curhan GC. Association of dietary patterns with albuminuria and kidney function decline in older white women: A subgroup analysis from the nurses health study. Am J Kidney Dis. 2011;57(2):245-54.

17. Kumar V, De La Vega LP, Farell G, Lieske JC. Urinary macromolecular inhibition of crystal adhesion to renal epithelial cells is impaired in male stone formers. Kidney Int. 2005;68(4):1784-92.

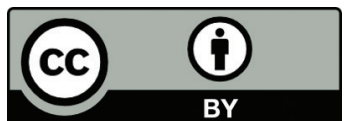

This work is licensed under a Creative Commons Attribution 